\title{
Keikhlasan Orang Tua yang Memiliki Anak Autisme
}

\author{
Abdussamad, Mulyani, dan Mahdia Fadhila \\ Universitas Islam Negeri Antasari Banjarmasin
}

\begin{abstract}
Having a child with perfect physical and psychological condition is everyone's dream. However, if the diagnosis states that the child has autism, it is not certainly easy for parents to accept. This aims of research are determining the sincerity of parents who have children with autism and what the factors which influence it. This research uses a descriptive qualitative method with a muslim couple, husband and wife, which have two autism children as subjects. The results showed that process towards sincerity between two subjects were different. When The SP subject knows the diagnosis results, he can control his emotions that what happened with them is God's provision. so that no matter what the conditions are, he must accept it. Meanwhile, SR subject took two weeks to convince herself about her children's conditions were still gifts from God and she must have to take care. The factors which influences of parents' sincerity are religious knowledges, patience, gratitude, religious understanding and resignation.
\end{abstract}

Keywords: sincerity of parents; autism; PLDPI South Kalimantan province.

\begin{abstract}
Abstrak
Mempunyai anak dengan keadaan sempurna secara fisik dan psikis adalah impian semua orang. Namun apabila diagnosa menyatakan anak mengalami autisme tentu bukanlah hal yang mudah bagi orang tua untuk menerimanya. Penelitian ini bertujuan untuk mengetahui gambaran keikhlasan orang tua yang memliki anak autisme dan faktor apa saja yang mempengaruhinya. Penelitian ini menggunakan jenis penelitian kualitatif deskriptif dengan subjek sepasang suami istri yang beragama Islam dan memiliki dua orang anak autisme. Hasil penelitian menunjukkan bahwa proses menuju keikhlasan antara kedua subjek terdapat perbedaan. Ketika subjek SP mengetahui hasi diagnosa ia dapat mengendalikan emosi bahwa apa yang terjadi merupakan ketentuan Allah sehingga bagaimanapun kondisinya harus tetap menerimanya. Sedangkan subjek SR membutuhkan waktu dua minggu untuk meyakinkan diri bahwa bagaimanapun kondisi anaknya tetap saja merupakan titipan dari Allah dan ia pasti bisa menjaganya. Adapun faktor yang mempengaruhi keikhlasan orang tua ialah pengetahuan agama, sabar, syukur, pemahamaan agama dan tawakkal.
\end{abstract}

Kata kunci: keikhlasan orang tua; autisme; PLDPI Provinsi Kalimantan Selatan.

Saat anak terdiagnosa autisme respon pertama yang muncul dari orang tua ialah perasaan negatif yakni tidak percaya, adanya penolakan, kecewa, dan sedih. Sebagian dari orang tua banyak meratapi nasib tersebut karena tidak tahu reaksi atau sikap apa yang harus diberikan. Banyak orang tua yang memutuskan untuk menutupi keadaan yang 
dimiliki anaknya baik kepada teman, lingkungan, tetangga bahkan keluarga, terkecuali kepada dokter yang memberikan penanganan dengan anaknya (Ninda Rian Astari, 2017).

Berdasarkan pernyataan sebelumnya peneliti melakukan studi pendahuluan kepada seorang ibu yang berinisial MD dan seorang bapak berinisal RD dengan tujuan untuk mengetahui respon awal orang tua ketika anaknya terdiagnosa autisme dan keadaan sekarang orang tua dengan anak autisme meliputi aspek pikiran, perasaan, dan perilaku. Dari hasil studi pendahuluan peneliti menemukan bahwa ketika mengetahui diagnosa anak, perasaan dominan yang ditunjukkan kedua subjek adalah emosi negatif yaitu sedih, kaget, dan bingung. Bahkan pada subjek MD, ia sempat mempertanyakan takdir Allah mengenai kondisi anaknya. Begitu pula pada subjek RD yang menyatakan bahwa kondisi yang dialami anaknya tidak seharusnya menimpa ia yang memiliki status ekonomi menengah ke bawah. Ditambah lagi dengan pengetahuan yang terbatas mengenai kondisi anak dengan autisme membuat kedua subjek kemudian mencari berbagai informasi terkait melalui internet dan bertanya dengan orang yang dianggap mengetahui hal tersebut. Meski awalnya kaget dan sedih, namun kedua subjek tetap menunjukkan upaya mencari tahu lebih lanjut tentang penanganan anak dengan autisme.

Seiring berjalannya waktu kedua subjek sekarang sudah bisa menerima anaknya dengan keadaan autisme dan kedua subjek sudah membuka pikiran bahwa terdapat hikmah yang tidak diketahui dari apa yang mereka alami. Sekarang kedua subjek berusaha memberikan yang terbaik untuk anaknya dengan membawanya ke tempat terapi dan mejalankan home program yang diberikan di tempat terapi. Usaha lain kedua subjek ialah dengan sering mendoakan kesembuhan anaknya. Pada subjek MD juga memperbanyak beribadah seperti menambah salat sunah tahajud. Selain itu kedua subjek juga merasa dituntut untuk menjadi pribadi yang lebih bersyukur atas setiap ketentuan yang telah diberikan Allah Swt.

Anak merupakan sebuah titipan atau amanah yang diberikan Allah Swt kepada orang tua. Anak adalah buah hati kebanggaan setiap keluarga. Anak juga merupakan penerus keturunan yang dapat membawa kemajuan pada masa akan datang. Al-Quran menyebutkan bahwa anak merupakan ujian untuk setiap orang tua sebagaimana dalam QS. al-Anfal ayat 28 yang berbunyi: 


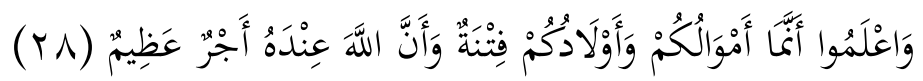

"Dan ketahuilah bahwa hartamu dan anak-anakmu itu hanya sebagai cobaan sesungguhnya di sisi Allah-lah pahala yang besar" (Q.S. al-Anfal ayat 28).

Ayat 28 pada surah al-Anfal tersebut menenerangkan bahwa Allah Swt memberikan salah satu ujian pada orang tua ialah dengan keberadaan anak yang dimiliki. Sehingga hendaknya setiap orang tua harus sungguh-sungguh dalam bertanggung jawab untuk menjalankan pemberian sekaligus ujian yang sudah ditetapkan Allah Swt (Astari, 2017). Sehingga orang tua harus memberikan dukungan dengan anak, karena dukungan orang tua sangat berpengaruh positif pada perkembangan anak (Pancawati, 2013). Orang tua harus mensosialisasikan anak, mengembangkan hubungan dengan teman sebaya dan meningkatkan prestasi belajar anak (Noor dkk., 2014). Kemudian apabila anak telah dibantu dengan terapi yang tepat, maka anak diharapkan akan bisa berinteraksi secara perlahan dengan lingkungan (Effendi, 2020). Dalam kelahiran anak al-Quran juga memberi tahu agar orang tua bersyukur serta ikhlas kepada Allah Swt, karena rasa ikhlas serta syukur akan sangat berpengaruh pada kondisi psikologis anak begitu juga dengan pola pendidikan yang akan diterapkan pada waktu yang mendatang (Kosim, 2013). Selain itu, jika seseorang menginginkan hidup tenang, tentram dan bahagia maka sangat dibutuhkan jiwa yang ikhlas sebagai dasar pijakan keberadaannya (Sentana, 2011).

Secara umum ikhlas diartikan sebagai sebuah ketulusan saat seseorang memberi pertolongan, penerimaan, dan kerelaan. Ikhlas sendiri berkaitan dengan persepsi, artinya bagaimana seseorang memberikan pandangan atas kondisi yang dijumpai. Ikhlas mempunyai kemampuan yang dapat ditingkatkan menjadi model terapi pada proses pengembangan kesehatan mental (Hadjam, 2011).

Dengan adanya pengertian ikhlas maka peneliti menambah data studi awal dengan melakukan wawancara kepada dua orang informan, yakni dengan seorang nenek berinisial NK yang mempunyai cucu autisme inisial KY dan dengan seorang terapis inisial ID. Hasil studi pendahuluan yang didapat berdasarkan cerita NK diketahui bahwa ayah dan ibu KY masih belum bisa menerima kondisinya, sehingga yang membawa KY ke tempat terapi adalah neneknya. Terapis ID juga menceritakan bahwa anak lain yang menempuh terapi di PLDPI tetapi ia juga masih belum bisa diterima ayahnya ialah berinisial MS, sehingga yang merawatnya sehari-hari adalah ibunya. 
Berdasarkan hasil wawancara dengan informan dan wawancara dengan dua subjek sebelumnya dapat dipahami bahwa hasil studi awal yang dilakukan peneliti bervariasi, ada orang tua yang bisa menerima kondisi anak dengan autisme dan masih ada orang tua yang menerima anaknya dengan keadaan autisme. Hal ini menjadi sebuah pertanyaan apa yang menjadi penyebab orang tua bisa menerima anaknya dengan keadaan autisme, apakah dipengaruhi oleh waktu, ataukah faktor dukungan sosial atau faktor ekonomi atau faktor lainnya. Dengan demikian peneliti tertarik untuk meneliti penerimaan, namun dalam perspektif Psikologi Islam yakni “Bagaimana keikhlasan orang tua yang memiliki anak autisme dan apa saja faktor yang mempengaruhi keikhlasan orang tua yang memiliki anak autisme di Pusat Layanan Disabilitas dan Pendidikan Inklusi Provinsi Kalimantan Selatan.

Penelitian ini diharapkan dapat memberikan kontribusi dalam disiplin ilmu Psikologi Islam, khususnya terkait keikhlasan orang tua yang memiliki anak autisme. Penelitian ini juga diharapkan dapat menjadi motivasi bagi orang tua yang memiliki anak autisme agar dapat ikhlas menerima kondisi anak dan segera mungkin memberikan penanganan untuk kesembuhannya. Sebab, jika tidak akan merugikan anak dan orang tua itu sendiri. Penelitian ini diharapkan juga bermanfaat dan dapat memberikan gambaran kepada pembaca terkait keikhlasan orang tua yang memiliki anak autisme.

\section{Metode}

Penelitian ini menggunakan jenis penelitian kualitatif deskriptif yakni dengan mendeskripsikan objek atau data yang diperoleh yang kemudian disampaikan dalam tulisan yang berbentuk naratif. Penelitian ini dilakukan di Pusat Layanan Disabilitas dan Pendidikan Inklusi Provinsi Kalimantan Selatan. Pemilihan subjek dalam penelitian ini menggunakan teknik purposive sampling dengan kriteria subjek adalah sepasang suami istri yang beragama Islam dan memiliki dua orang anak autisme yang sedang menjalani terapi di Pusat Layanan Disabilitas dan Pendidikan Inklusi Provinsi Kalimantan Selatan. Penelitian ini mengkaji bagaimana proses keikhlasan orang tua yang memiliki anak autisme dan apa saja faktor yang mempengaruhi keikhlasan orang tua. Teknik pengumpulan data melalui wawancara semi terstruktur, observasi non partisipan, dan dokumentasi. Wawancara dilakukan berdasarkan aspek riwayat autisme anak, proses penerimaan dan kondisi sekarang. Adapun teknik analisis data menggunakan model Miles and Huberman yakni dengan tahapan reduksi data, penyajian data, dan penarikan kesimpulan atau verifikasi. 


\section{H a s i 1}

Pelasksanaan penelitian dilakukan pada tanggal 29 Desember 2020 dan 7, 10 Februari 2021, dengan jumlah responden sebanyak dua orang dengan data sebagai berikut:

Tabel 1. 1

Identitas Subjek penelitian

\begin{tabular}{ccccccc}
\hline No & $\begin{array}{c}\text { Subjek } \\
\text { (Inisial) }\end{array}$ & $\begin{array}{c}\text { Usia } \\
\text { (th) }\end{array}$ & Pekerjaan & $\begin{array}{c}\text { Lama bekerja } \\
\text { (th) }\end{array}$ & Status & Alamat \\
\hline 1. & SR & 34 & Pedagang & 12 & Istri & $\begin{array}{c}\text { Banjarmasin } \\
\text { Utara }\end{array}$ \\
2. & SP & 45 & Office Boy & 12 & Suami & $\begin{array}{c}\text { Banjarmasin } \\
\text { Utara }\end{array}$ \\
\hline
\end{tabular}

Objek dalam penelitian ini ialah keikhlasan pada orang tua yang memiliki anak dengan autisme meliputi bagaimana gambaran keikhlasan orang tua yang memiliki anak autisme dan faktor apa saja yang berpengaruh terhadap keikhlasan orang tua yang memiliki anak autisme. Objek penelitian tersebut akan digali melalui wawancara semi terstruktur, yakni peneliti menyipakan daftar pertanyaan yang mana tidak menutup kemungkinan ditengah proses wawancara terdapat pertanyaan baru yang tidak terdapat di daftar pertanyaan sebelumnya. Kemudian juga dilakukan observasi non-partisipan yang artinya peneliti hanya melakukan observasi pada saat wawancara dengan subjek penelitian dan langkah selanjutnya adalah dokumentasi. Setelah melakukan wawancara, observasi dan dokumentasi, data yang didapat dilapangan akan dilakukan analisis dengan mengggunakan model Miles and Huberman yakni dengan melakukan reduksi data, penyajian data dan penarikan kesimpulan atau verifikasi. Peneliti juga membandingkan data yang di dapat dari sumber primer dan sumber sekunder.

\section{Riwayat Autisme}

Pada masa kehamilan ananda AS, subjek SR tidak mengalami kendala apa pun hanya saja subjek SR pernah mengidam ikan pindang lajang basah yang merupakan ikan laut. Subjek SR mendapatkan informasi dari Dokter bahwa ada kemungkinan yang menjadi pemicu ananda AS mengalami autisme adalah hal tersebut. Sementara pada proses kehamilan yang dilalui ananda IL juga tidak mengalami kendala apapun. Namun, yang menjadi dugaan subjek SR ialah karena proses pengobatan yang belum bersih sebab jangka operasi tumor payudara dengan kehamilan tidak sampai satu tahun. Adapun proses 
kelahiran ananda AS harus melalui proses induksi dikarenakan umur bayi dalam kandungan menginjak waktu 10 bulan 5 hari. Sedangkan kelahiran ananda IL melalui operasi cesar dikarenakan lingkar kepala bayi lebih besar daripada bayi pada umumnya.

Pasangan suami istri ini mulai menyadari bahwa ada beberapa kejanggalan pada proses tumbuh kembang ananda AS seperti tidak ada tindakan berupa kontak mata saat diberikan kata (O'ko). Saat ananda AS dibaringkan di tempat tidur walaupun seharian, ia hanya diam tanpa tindakan apa pun yang sekiranya pada bayi berusia 2 bulan lakukan. Ia hanya memberikan sinyal atau tindakan pada saat ingin buang air kecil dan buang air besar serta haus atau lapar. Menginjak usia dua tahun ananda AS masih tidak dapat berbicara, tidak seperti anak-anak pada umumnya. Melihat perbedaan yang ada pada anak subjek SR tetangga mulai menyarankan agar ananda AS dibawa ke pengobatan alternatif. Di tempat pengobatan alternatif itulah subjek SR mengetahui bahwa ananda AS mengidap autisme.

Menginjak usia tujuh tahun ananda AS memiliki seorang adik berinisial IL. Beranjak ananda IL saat usia dua tahun, subjek SR mulai merasa ada kejanggalan pada masa tumbuh kembangnya. Kejanggalan tersebut seperti mengulang hal yang sama saat masa tumbuh kembang anak pertamanya dulu. Sehingga ananda IL dibawa ke Tumbuh Kembang untuk dilakukan pemeriksaan dengan hasil Speech Delay. Hasil pemeriksaan tersebut membuat subjek SR merasa mendapat tamparan keras. Hal inilah yang membuat pemikiran bangkit dari keterpurukan subjek SR ada, Subjek memilih memberikan penanganan dengan membawa ananda IL ke tempat terapi ABK yang bertempat di Rumah Sakit Ulin Banjarmasin. Dua tahun setelahnya ananda IL menjadi penyandang autisme dan akhirnya kedua anaknya menjalani terapi di PLDPI Provinsi Kalimantan Selatan. 
Skema 1.1

Riwayat Autisme Anak

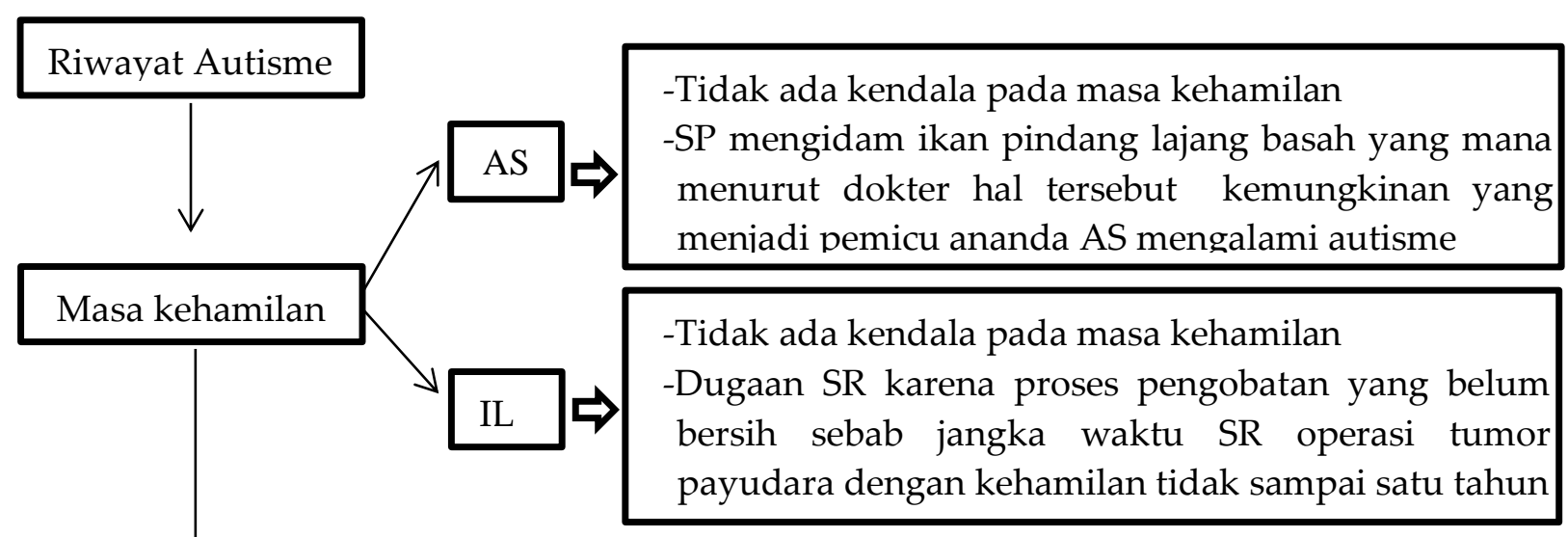

Kelahiran melalui proses induksi dikarenakan umur bayi dalam kandungan menginjak waktu 10 bulan 5 hari.

Kelahiran melalui proses bedah caesar dikarenakan ukuran lingkaran kepala bayi lebih besar dari ukuran kepala bayi normal umumnya

-Jika dibaringkan ditempat tidur diam tanpa respon yang seharusnya dilakukan pada bayi berusia 2 bulan, respon hanya ada ketika ingin $\mathrm{BAK}, \mathrm{BAB}$, haus, dan lapar

-Usia 2 bulan ketika diberikan kata ( $\left.\mathrm{O}^{\prime} \mathrm{ko}\right)$ tidak memberikan respon kontak mata

-Adanya kemiripan dengan ananda AS yakni tidak terlalu rewel seperti bayi pada umunya.

-Ketika ada yang mengajak bicara masih memberikan kontak mata

-Ketika sang ibu memberikan kata ( $\left.\mathrm{O}^{\prime} \mathrm{ko}\right)$ ananda IL memberikan respon kontak mata tetapi sebentar saja.

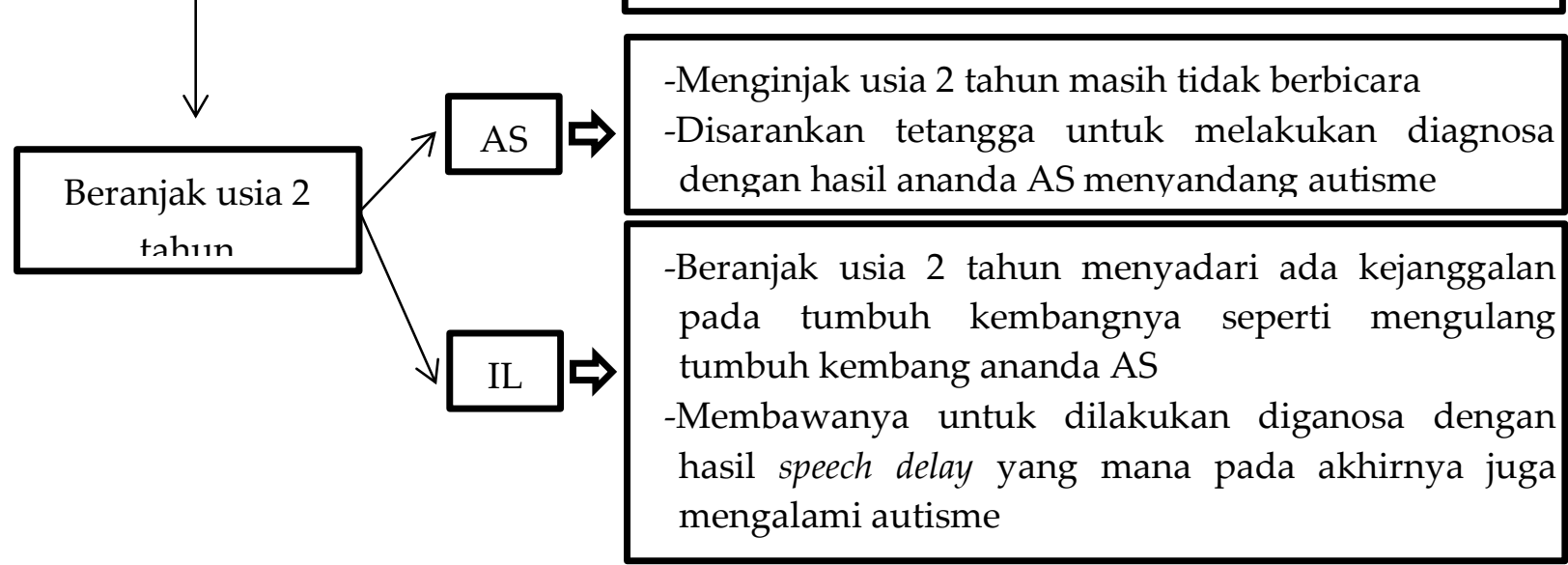

Keterangan : AS adalah anak pertama : IL adalah anak kedua 


\section{Proses Penerimaan}

Proses penerimaan yang dilalui kedua subjek terdapat perbedaan. Ketika subjek SP mengetahui kondisi anaknya menyandang autisme sempat kaget, namun dengan kedewasaannya membuat subjek SP mampu untuk membuka pikiran bahwa kondisi yang dialami anaknya merupakan ketentuan yang sudah diberikan Allah Swt sehingga harus tetap bisa menerimanya. "Ketika baru tau itu ya kaget juga terus. Awalnya kan mau anak yang normal jugakan nih, Tetapi sudah ketentuan-Nya mengalami autisme, ya mau tidak mau, karena ketentuan pemilik-Nya yang mengatur, ya sudah terima saja". Sedangkan perasaan yang ditunjukkan subjek SR adalah emosi negatif yakni kaget, sedih, dan bingung. Selama satu minggu subjek SR memilih mengurung diri di rumah dan membutuhkan waktu dua minggu untuk dapat memunculkan emosi positif yakni meyakinkan diri atas kondisi anaknya ananda AS yang merupakan titipan dari Allah Swt dan ia pasti bisa menjaganya. "Awalnya kan sempat drop dan kecewa, tetapi untuk meyakinkan diri bahwa itu titipan dan kami pasti bisa menjaganya, perlu waktu kurang lebih dua minggu sih". Namun tindakan kedua subjek dalam memberikan penanganan adanya setelah ananda AS menginjak usia 9 tahun dan adiknya ananda IL beranjak usia 2 tahun sebagai penyandang speech delay. Sebab inilah subjek SR merasa mendapat tamparan keras dan membuatnya bangkit dari keterpurukan. "Umur 7 tahun kan dia mempunyai adik. Posisinya ketika mempunyai adik. Adiknya e'em, nah ketika ini baru saya dapat tamparan keras sehingga muncul lagi semangat saya". Sehingga saat ini kedua anaknya sudah mendapatkan terapi di PLDPI Provinsi Kalimantan Selatan dan ananda AS juga sudah mulai masuk di Sekolah Luar Biasa yang berada di Jalan Kayutangi.

Perasaan kedua subjek dalam merawat ananda AS dan IL senang apabila mereka berdua lagi pintar dan sehat. Sebaliknya ketika kondisi mereka mulai tantrum, mengamuk, atau menolak di ajarkan kadang kedua subjek emosi dan merasa jenuh. Cara subjek SR menenangkannya adalah dengan mendiamkan diri di kamar. Sedangkan subjek SP dengan cara pergi ke Majelis ataupun sambil mendoakan kembali semoga kedua anaknya bisa mandiri. Adapun yang menjadi tantangan kedua subjek dalam merawat anaknya ialah dalam menghadapi perilakunya sehari-hari termasuk menjalankan home program ataupun menjalankan dietnya.

Niat kedua subjek dalam merawat anak adalah untuk menjalankan tanggung yang sudah diberi, sehingga bagaimanapun kondisi anaknya tetap wajib untuk mendidik dan 
memenuhi kebutuhannya hingga kembali kepemilik-Nya. "Niatnya sih menunaikan kewajiban yang sudah diberikan sih. Karena saya diberi anak yang begini ya berarti itu kewajiban saya sudah, mendidik mengasih makan dan segalanya. Wajib sampai suatu saat nanti kembali lagi ke pemilikNya" ucap subjek SR. "Niat mengasuh, ya karena tanggung jawab, mudahan dia sembuh kalau bisa" ucap subjek SP. Adapun amalan kedua subjek dalam merawat anak dengan memperbanyak membaca selawat dan memperbanyak doa untuk kesembuhannya. Subjek SP juga membiasakan membaca surat yasin setelah sholat magrib dan mengajak kedua anaknya duduk di samping agar mereka ikut mendengarkan. "Amalan lah ? ya baca yasin, yasin sih, sholawat dan berdo'a meminta kesembuhan kepada pemilik-Nya agar mereka bisa mandiri" ucap subjek SP. Sekarang kedua subjek sudah bisa menerima dan yakin bahwa Allah Swt memberi sesuatu karena memang mampu dan bisa menjaga amanah yang diberi. "sudah ikhlas sih, karena sepenuhnya kan Allah itu memberi sesuatu ke kita itu kan karena memang kita mampu dan memang percaya bahwa kita bisa menjaga amanah yang sudah diberi" ucap subjek SR. Subjek juga yakin bahwa pasti ada sesuatu yang indah yang sudah disiapkan Allah Swt. 
Skema 1.2 Proses Penerimaan
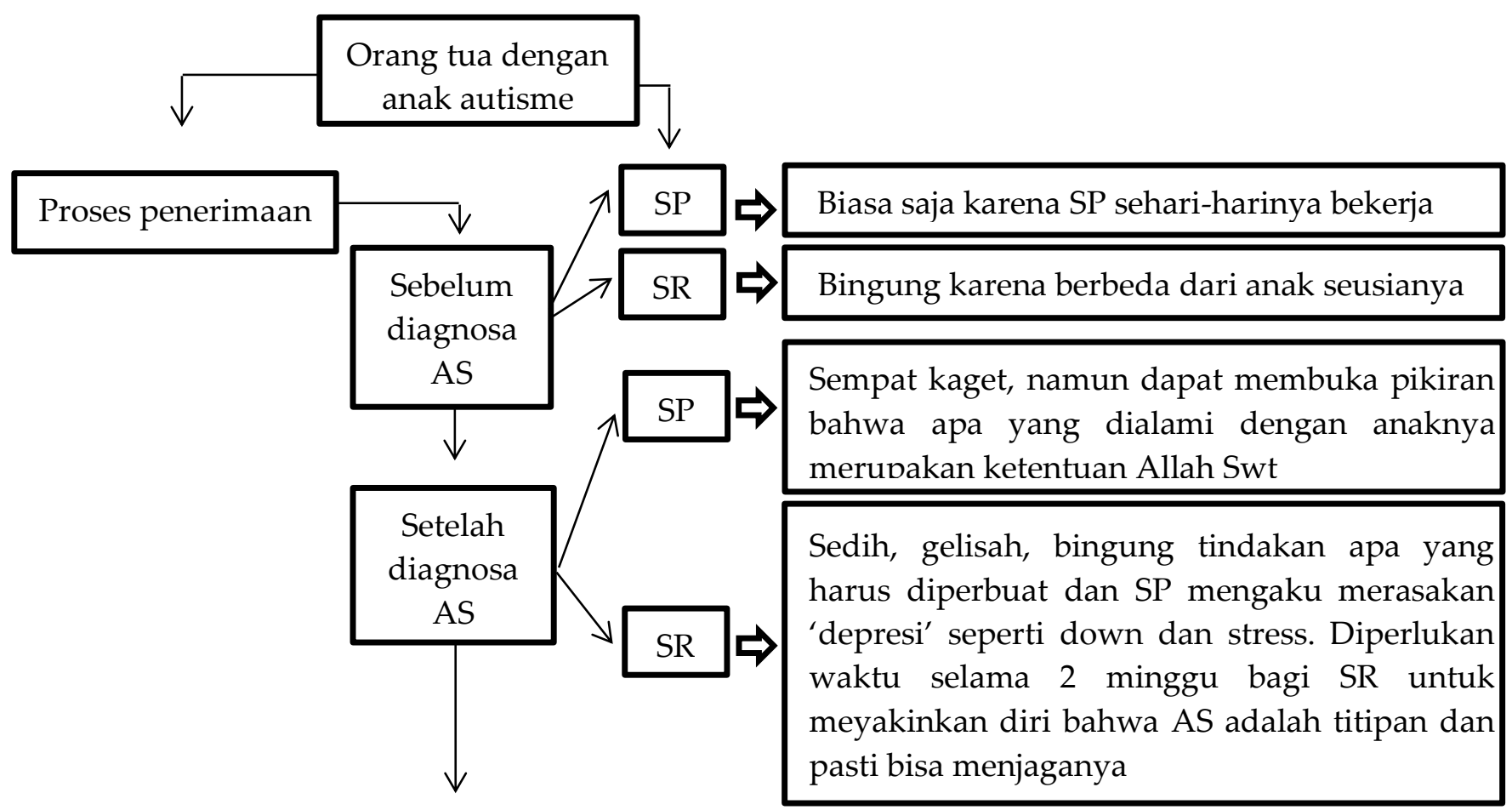

Penanganan diberikan ketika AS menginjak usia 9 tahun dan IL beranjak usia 2 tahun dengan diagnosa speech delay. AS menjalani terapi di PLDPI dan IL di Rehab Medis Rumah Sakit Ulin

Setahun setelah terapi di Rehab Medis RSU IL didiagnosa autisme dan keduanya sekarang menjalani terapi di PLDPI dan AS juga

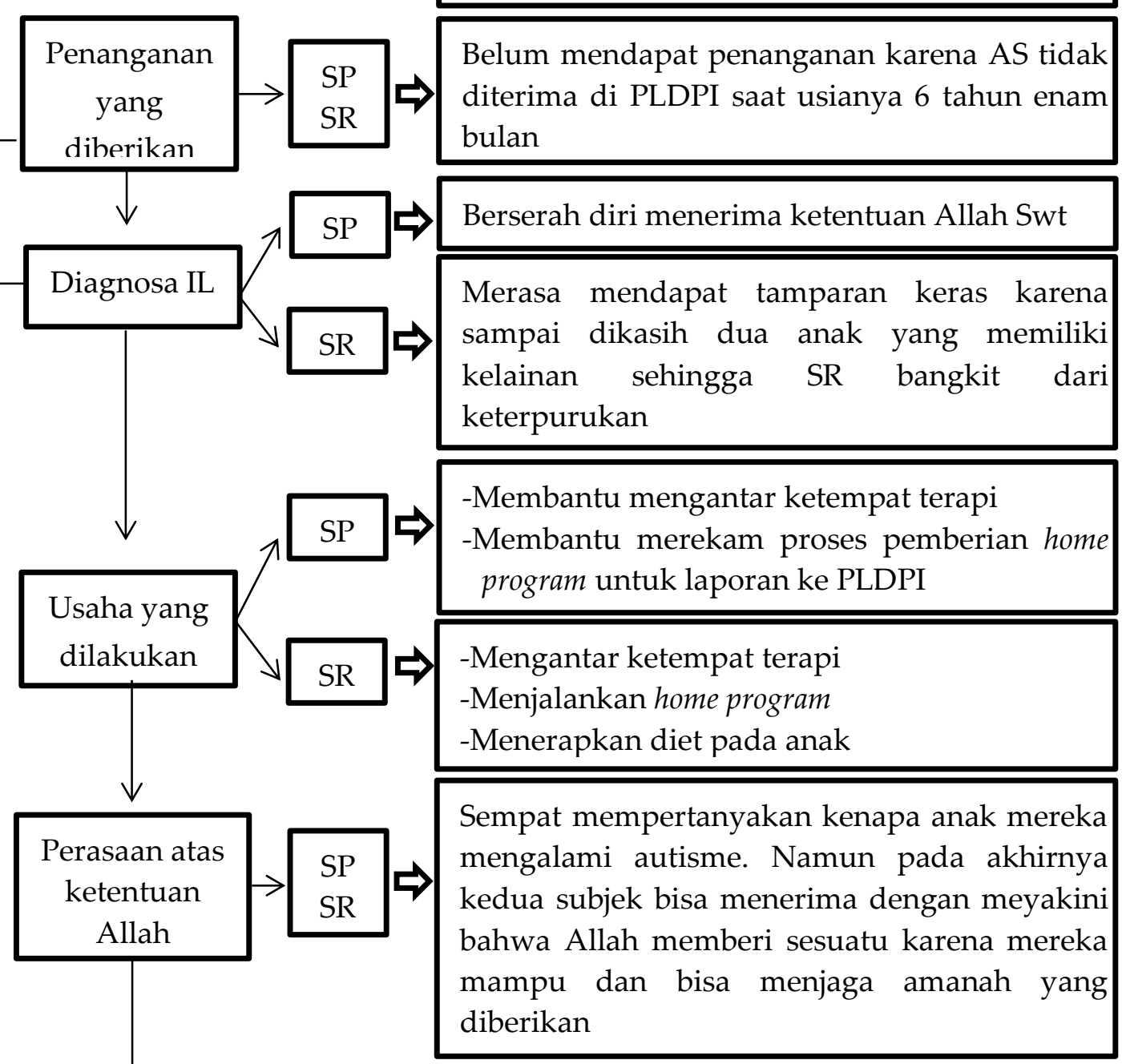

Keterangan : SP adalah Ayah : SR adalah Ibu Adanya dukungan dari keluarga dan lingkungan sekitar dalam mengasuh anak 


\section{Kondisi Sekarang}

Kondisi sekarang yang dialami kedua anak subjek semenjak mengikuti terapi pada PLDPI sudah banyak mengalami perkembangan yang positif. Masa yang dihabiskan ananda AS dalam proses terapi di PLDPI adalah selama tiga tahun, dimulai dari ananda berusia sembilan tahun hingga sekarang sudah berumur dua belas tahun. Perkembangan yang spesifik terjadi terhadap kedua anaknya membuat subjek SR sangat senang karena sudah tidak memerlukan tenaga dan kontrol emosi yang besar untuk menangani dan merawat mereka berdua.

Kedua subjek sekarang juga sudah mulai kembali percaya diri dan tidak tertekan dengan keadaan yang dihadapi anaknya. Kedua subjek juga meyadari bahwa perkembangan yang terjadi pada kedua anaknya karena hasil terapi, tidak hanya karena dirinya melainkan merupakan hasil usaha berbagai pihak yang mendukung anaknya. Mulai dari suami, kemudian kakek dan neneknya serta pihak tetangga lingkungan sekitar dan pihak terapis di PLDPI Provinsi Kalimantan Selatan, tak terkecuali Allah Swt yang mengabulkan doa mereka. "Dari hasil semua orang yang terkait sih. Dari terapisnya, neneknya, bapaknya juga, semua sih, semuaa... aspek yang mendukung termasuk Allah. Kadangkan seperti anak tetangga disebelah juga mau aja nemanin AS, dia sebaya kan dengan AS tetapi perempuan. Dia masih mau saja gandeng-gandeng nemenin AS masih mau. Cuman sekarang karena musim sakitsakit seperti ini, agak kurang berteman" ucap subjek SR. "Ya, gara-gara diberi terapi jua pang (ya, sebab diberi terapi juga sih). Karena sering dibawa istri saya diterapi kan, di ajak terapi disekolah juga, karena sering juga mendo'akan. Terus neneknya juga yang membantu menjaganya setiap hari" ucap subjek SP.

Kedua subjek sekarang sedang mencoba memperbanyak membaca selawat. Pada Subjek SP juga meningkatkan kegiatan dalam hal beribadah seperti lebih sering membaca Yasin dan pergi ke Majelis ilmu. Kedua subjek pun juga menyadari agar berusaha lebih sabar lagi dalam merawat ananda AS dan ananda IL. Kedua subjek sudah memilih lebih mendekatkan diri kepada Allah namun tidak dapat dipungkiri bahwa terkadang kedua subjek masih ada perasaan khawatir apabila muncul pikiran jika seandainya di antara mereka ada yang meninggal dunia, siapa yang akan merawat kedua anaknya. Apabila mulai muncul pikiran yang demikian kedua subjek menenangkan diri kembali dengan 
mengingat pemilik-Nya bahwa ada Allah Swt yang mengatur dan menjaganya. Adapun hikmah dan pembelajaran yang dapat diambil dari kedua subjek dengan adanya ananda AS dan ananda IL ialah mereka dituntut untuk belajar menjadi pribadi yang lebih sabar dan bersyukur serta belajar menerima setiap ketentuan yang diberikan Allah Swt.

\section{Pembahasan}

\section{Proses Keikhlasan Orang Tua}

Saat mengetahui anak autisme tanggapan pertama yang muncul dari orang tua ialah perasaan negatif yakni tidak percaya, adanya penolakan, kecewa, dan sedih. Sebagian dari orang tua banyak meratapi nasib terebut karena tidak tahu reaksi atau sikap apa yang harus diberikan. Banyak orang tua yang memutuskan untuk menutupi keadaan yang dimiliki anaknya baik kepada teman, lingkungan, tetangga, bahkan keluarga, terkecuali kepada dokter yang memberikan penanganan dengan anaknya (Astari, 2017). Serupa dengan reaksi subjek SR ketika pertama kali mengetahui kondisi anaknya autisme yang muncul ialah perasaan sedih dan gelisah, sedangkan tanggapan yang ditunjukkan subjek SP ialah perasaan kaget. Pengetahuan yang terbatas membuat kedua subjek bingung bagaimana cara menangani anak autisme. Hasil pemeriksaan dan pernyataan dari pihak-pihak tertentu yang seolah menyalahkan dirinya atas penyakit yang diderita anaknya membuat subjek SR bertambah down dan membuatnya tidak ada keinginan untuk mencari tahu tentang anak autisme. Selama satu minggu subjek SR mengurung diri di rumah dan membiarkan keadaan anaknya terkecuali memenuhi kebutuhannya sehari-hari. Penelitian yang dilakukan Pittari Mashita Purnomo juga serupa bahwa sebagain besar orang tua merasa sedih karena anaknya berbeda dengan anak normal lainnya, kemudian juga bingung tindakan apa yang harus dilakukan. Sebagian orang tua juga berusaha pasrah menerima kondisi anaksebaliknya juga ditemukan orang tua yang masih melakukan penolakan, menyalahkan diri sendiri dan orang lain, namun ia berusaha berdamai dengan dirinya sendiri dan pasrah menerima kondisi anak.

Bagi orang tua yang hidup bersama anak autisme langkah terbaik dalam menjalani kehidupan ialah dengan rasa ikhlas dalam memilikinya dan menerimanya secara lapang dada. Jangan segan untuk membiasakan anak bertemu dan berinteraksi dengan masyarakat banyak (Effendi, 2020) karena akan mempengaruhi interaksi anak dengan lingkungan. Serupa dengan subjek SP mampu memunculkan emosi positif dengan membuka pikiran 
bahwa bagaimanapun kondisi yang dialami anaknya ia harus bisa menerimanya karena itu semua merupakan ketentuan yang sudah diberikan Allah Swt. Subjek SP juga terbuka dengan lingkungan sekitar untuk membawa anaknya berjalan. Sedangkan respons pertama subjek SR ketika mengetahui anaknya terdiagnosis autisme ialah bentuk penolakan, muncul perasaan minder kepada orang banyak atas apa yang diderita anaknya. Membutuhkan waktu selama dua minggu bagi subjek SR untuk mencoba meyakinkan diri bahwa ananda AS adalah titipan dari Allah Swt dan ia pasti bisa menjaganya. Sama halnya dengan penelitian yang dilakukan Pittari Mashita Purnomo tahapan selanjutnya setelah penolakan anak dengan autisme ialah memilih untuk pasrah dan mencoba menerima keadaan anggota keluarga yang autisme dengan tenang.

Cara yang dilakukan orang tua yang tinggal bersama anak autisme untuk menghadapi masalah yang terjadi adalah dengan cara assistance seeking, information seeking (Marettih \& Wahdani, 2017). Assistance seeking yang dilakukan subjek SP dengan berusaha terbuka dengan lingkungan sekitar terkait kondisi yang dialami anaknya. sedangkan subjek SR berawal dari masukan tetangga untuk membawa anaknya melakukan pemeriksaan. Sedangkan information seeking yang dilakukan subjek SR ialah dengan mendatangi dokter untuk mengetahui apa yang terjadi dengan anaknya. Setelah melewati masa penolakan atas kondisi yang diderita anaknya, sedikit demi sedikit mulai mencari informasi tentang anak autisme.

Orang tua juga harus memberikan dukungan dengan anak, karena dukungan orang tua sangat berpengaruh positif pada perkembangan anak (Pancawati, 2013). Orang tua harus mensosialisasikan anak, mengembangkan hubungan dengan teman sebaya dan meningkatkan prestasi belajar anak (Noor dkk., 2014). Kemudian apabila anak telah dibantu dengan terapi yang tepat, maka anak diharapkan akan bisa berinteraksi secara perlahan dengan lingkungan (Effendi, 2020). Penanganan terjadi sejak ananda AS berusia 9 tahun adiknya yang bernama IL sudah beranjak usia 2 tahun dimana didiagnosa speech delay. Hasil pemeriksaan tersebut membuat subjek SR merasa mendapat tamparan keras sehingga membuatnya bangkit dari keterpurukan.

Niyat, merupakan komitmen ilahiyyah yang menjadi motivasi seseorang dalam beraktivitas untuk mencapai kata amanah. Apabila kegiatan yang manusia lakukan tanpa niat maka tidak akan dirasa sebagai suatu ibadah. Niat juga harus didasari oleh kemauan 
(al-iradah) dan kemampuan (al-qudrah) agar dapat mewujudkan perilaku baik. Af'al adalah melaksanakan apa yang pernah terlintas dalam azam dan niat. (Mujib, 2017). Serupa dengan kedua subjek mempunyai niat yang tulus dan berusaha untuk merealisasikan niat tersebut dengan sungguh-sungguh untuk kesembuhan kedua anaknya. Namun, dalam merealisasikan niat tidak semata-mata berjalan mulus, salah satu tantangan yang dihadapi ialah fase naik turun emosi dan perilaku anak apabila sewaktu-waktu mengalami tantrum. Tantangan lain atau hal yang menjadi perhatian utama subjek SR, yaitu mengenai pola makan dan diet yang harus dijalani anaknya karena pola diet yang dilakukan terkadang membuat anak merasa bosan karena menu makan selalu sama. Berkesesuaian dengan pernyataan Marettih \& Wahdani bahwa yang menjadi tantatangan ialah perilaku tantrum anak yang menyebabkan orang tua mengalami kebingungan dan merasa tertekan.

Hendaknya setiap orang tua benar-benar bertanggung jawab terhadap amanah yang diberikan Allah Swt sekaligus menjadi batu ujian yang harus dijalankan. Bagi orang tua yang memiliki anak autisme (Astari, 2017) langkah terbaik yang harus dilakukan adalah ikhlas, menerima kondisi anak dengan lapang dada (Effendi, 2020). Sebab rasa ikhlas serta syukur akan sangat berpengaruh pada kondisi psikologis anak begitu juga dengan pola pendidikan yang akan diterapkan pada waktu yang mendatang (Kosim, 2013). Serupa dengan kedua subjek yang mengungkapkan bahwa sudah menjalankan tanggung jawab sebagai orang tua. Kedua subjek juga sudah bisa ikhlas dengan ketentuan yang diberikan Allah Swt dengan meyakini bahwa Allah Swt menitipkan ananda AS dan ananda IL karena mereka mampu untuk menjaganya. Sehingga kedua subjek mengusahakannya untuk memberikan penanganan terapi. Dengan ikhlas dan ikhtiar penanganan yang diberikan membuahkan hasil, kedua anak subjek mengalami perkembangan positif hingga sekarang ananda AS sudah masuk di Sekolah Luar Biasa yang berada di Jalan Kayutangi.

Orang yang ikhlas tidak akan terpengaruh dan terkecoh oleh pujian dan sanjungan. Ia juga tidak akan terpengaruh dan berubah sikapnya apabila mendapatkan celaan dari orang lain, bahkan ia lupa kepada amal yang dilakukan dan tak mengharap sedikit pun imbalan dari Allah Swt. Itulah tanda bahwa ia telah benar dalam menerapkan keikhlasannya (Mustafa, 2012). Serupa dengan subjek SP dan subjek SR apabila mendapatkan tanggapan dari lingkungan sekitar yang merasa biasa-biasa saja. Kedua 
subjek juga mengutarakan biasa saja dalam menanggapi pujian dan subjek SR sendiri mengatakan tidak terlalu suka dengan pujian.

Orang yang ikhlas ia tidak akan mengawali pembicaraan tentang dirinya dengan memuji dan menceritakan dirinya di setiap majelis yang pernah ia duduki. (Mustafa, 2012). Serupa dengan subjek SP dan subjek SR yang tidak membanding-bandingkan kelebihan tumbuh kembang anaknya dengan anak lain. Kedua subjek hanya meperhatikan perkembangan anaknya, bagaiamana kondisi sekarang dan kondisi sebelumnya.

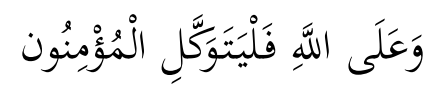

"Dan hanya kepada Allah sajalah hendaknya orang-orang mukmin bertawakkal." (Q.S. Ibrahim ayat 11)

Ayat 11 pada surah Ibrahim memberikan seruan agar seorang muslim hanya menyandarkan diri kepada Allah Swt bukan kepada sesama makhluk yang lain di samping kepada Allah Swt (Nakhrawie, 2020). Selain berbagai usaha yang dilakukan, turning to religion kedua subjek ialah dengan berpegang menjalankan perintah Allah Swt dalam mengasuh anak dengan memperbanyak amalan dan berdoa mengharap agar anak mereka berkembang dengan baik hingga ananda AS dan ananda IL bisa mandiri. Apabila muncul rasa khawatir meninggal dunia, kedua subjek juga kembali mengingat pencipta-Nya, bahwa ada Allah Swt yang mengatur dan menjaga anak mereka.

Menurut Ibn Qayyim karakter ikhlas terbagi menjadi tiga tingkatan: Pertama, tidak menganggap bernilai atas perbutan yang dilakukan. Kedua, adanya perasaan malu atas perbuatan yang dilakukan dan berusaha memperbaiki dan berharap agar apa yang dilakukan dalam cahaya tawfiq (pertolongan) Allah SWT, dan ketiga berbuat ikhlas melalui keikhlasan berdasarkan ilmu dan hukum-hukum Allah Swt (Mujib, 2017). Berkesesuaian dengan karakter ikhlas yang disampaikan Ibn Qayyim pada tingkatan kedua yakni adanya penyesalan berupa tindakan kekerasan dalam merawat seperti mencubit atau memukulnya apabila dengan cara menegurnya sudah tidak mempan. Usaha subjek SP meperbaiki perbuatan tersebut dengan cara menyalahkan dirinya sendiri atas apa yang ia lakukan dan berusaha menanamkan untuk tidak mengulanginya kembali, sedangkan pada subjek SR ialah dengan cara mengobatinya apabila ada meninggalkan bekas dan memberikan kasih sayang kembali dengan mengajak mereka berbicara seperti menyampaikan ucapan permintaan maaf. 
Terlepas dari itu hikmah yang dirasakan kedua subjek ketika memiliki anak autisme ialah syukur dan sabar. Meskipun memiliki anak yang terlahir tidak dalam keadaan normal kedua subjek mampu mensyukurinya dengan memandang bahwa kondisi yang dialami anaknya tidak tergolong ke dalam autisme yang berat. Sikap tantrum yang kadang muncul secara tiba-tiba atau adanya penolakan dalam pemberian home program menjadi kendala tersendiri bagi kedua subjek. Namun kendala tersebut justru juga merupakan hikmah bagi kedua subjek untuk melatih diri menjadi pribadi yang lebih sabar lagi. Menurut Abdul Mujib, sabar ialah menahan dan mengendalikan diri dari hal-hal yang dibenci dan menahan lisan agar tidak mengeluh. Sedangkan syukur artinya menampakkan nikmat yang diberikan Allah Swt kepadanya. (Mujib, 2017). 
Skema 1. 3 Proses Keikhlasan

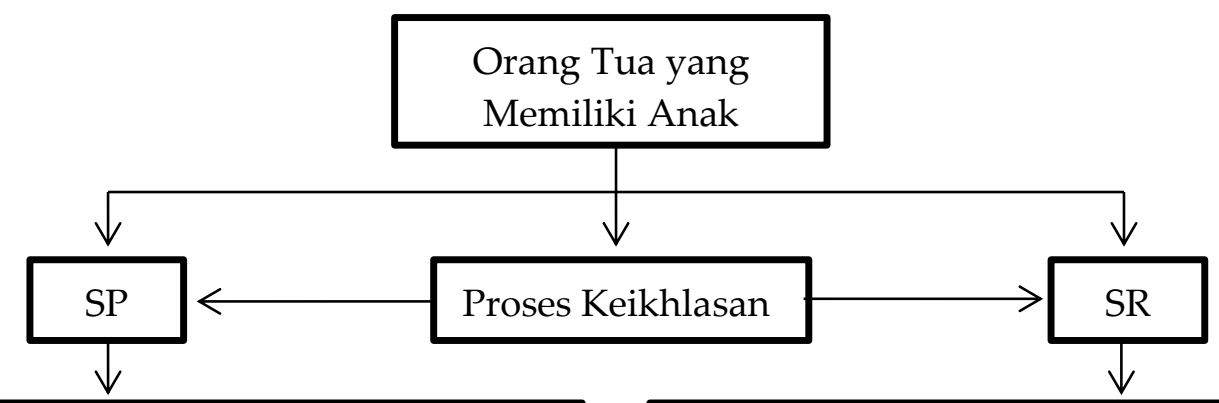

Mengetahui hasil pemeriksaan yang muncul ialah bentuk penolakan dan perasaan minder. Membutuhkan waktu selama dua minggu bagi subjek SR untuk mencoba meyakinkan diri bahwa ananda AS adalah titipan dari Allah Swt dan ia pasti bisa menjaganya

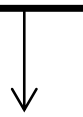

Pasrah menerima ketentuan Allah Swt

Membantu mengantar ananda IL dan neneknya ke ABK Rumah Sakit Ulin sembari berangkat kerja karena tujuan nya satu arah

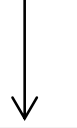

Di samping menyadari adanya tanggung jawab sebagai orang tua juga muncul niat untuk kesembuhan anak dan berusaha merealisasikan dengan sungguh-sungguh
Mengetahui hasil pemeriksaan sempat terkejut namun pada saat itu pula dapat membuka pikiran bahwa bagaimanapun kondisi yang dialami anaknya ia harus bisa menerimanya karena itu semua merupakan ketentuan yang sudah diberikan Allah Swt

$$
\downarrow
$$

Hasil pemeriksaan speech delay pada anak kedua membuat subjek merasa mendapatkan tamparan keras sehingga subjek bangkit dari keterpurukan

$$
\downarrow
$$

Kedua anaknya mendaptkan penanganan. Ananda IL di ABK Rumah Sakit Ulin dan ananda AS di PLA yang sekarang berganti nama PLDPI

\section{$\downarrow$}

Adanya kesadaran akan kewajiban yang diberikan Allah Swt, jadi bagaimanapun kondisi yang ada pada kedua anaknya ia harus tetap merawat dan mendidiknya hingga sampai pada masanya ia kembali kepada Allah Swt.

Di samping mengusahakan anak dengan memberikan penanganan, menjalankan home program dan diet anak, kedua subjek juga lebih mendekatkan diri kepada Allah Swt dengan memperbanyak membaca selawat, lebih sering membaca surah Yasin dan mendo'akan kesembuhan anak. Sekarang kedua subjek sudah bisa menerima kondisi anaknya dengan ikhlas dan usaha yang dilakukan membuahkan hasil yakni ananda AS sudah masuk di Sekolah Luar Biasa yang berada di Jl. Kayutangi

Keterangan : AS adalah anak pertama

: IL adalah anak kedua

: SP adalah Ayah

: SR adalah Ibu 


\section{Faktor yang Mempengaruhi Keikhlasan Orang Tua}

Mustafa mengatakan bahwa untuk mengukur keikhlasan seseorang merupakan sesuatu yang tidak mudah, karena karakter ikhlas sifatnya dirasakan dalam batin dan hanya diketahui oleh Allah dan pemilik keikhlasan itu sendiri. Kemudian karakter ikhlas juga memiliki komponen-komponen yang menjadi pendukung keikhlasan itu sendiri, beberapa sikap tersebut diantaranya zuhud, syukur, wara', sabar, dan tawakkal (Nur Khadijah, 2018).

Beberapa faktor yang mendukung atau mempengaruhi keikhlasan subjek dalam penelitian ini yang dapat peneliti garis bawahi ialah (1) Pemahaman agama, dibuktikan dengan subjek yang menanamkan bahwa anak adalah titipan dari Allah swt sehingga mereka sebagai orang tua harus bertanggung jawab atas amanah yang diberikan. (2) Sabar, sikap sabar diambil berdasarkan kemampuan subjek dalam merawat, mendidik, dan mengatasi perilaku anak dalam sehari-hari hingga sekarang. (3) Syukur, sikap syukur diambil berdasarkan pengakuan kedua subjek dalam perkembangan anak bahwa ada Allah yang berperan mengabulkan doa mereka. Kemudian kedua subjek juga menyatakan bersyukur karena anaknya tidak tergolong ke dalam autisme yang berat dan sekarang merawat anaknya sudah tidak susah seperti dulu lagi. (4) Keyakinan, dibuktikan dengan keyakinan kedua subjek bahwa Allah Swt menitipkan anak dengan autisme karena mereka mampu untuk menjaganya. (5) Tawakkal, disamping berbagai usaha yang dilakukan kedua subjek untuk kesembuhan anaknya, kemudian subjek berserah diri kepada Allah Swt dengan membaca surat yasin, memperbanyak berselawat dan lebih sering mendengarkan bacaan ayat al-Quran serta berdoa mengharap agar apa yang dia usahakan membuahkan hasil.

\section{Kesimpulan}

Proses menuju keikhlasan sepasang suami istri ini terdapat perbedaan. Saat mengetahui hasil pemeriksaan tanggapan yang ditunjukkan suami ialah emosi positif. Meskipun sempat kaget, ia dapat mengendalikan emosi bahwa apa yang terjadi pada anaknya merupakan ketentuan Allah Swt sehingga bagaimana pun kondisinya ia harus tetap menerimanya. Sedangkan tanggapan yang ditunjukkan istri adalah emosi negatif yakni perasaan sedih dan gelisah. Ia juga mengaku merasakan 'depresi' seperti down dan stres karena mendapat pernyataan dari pihak-pihak tertentu yang seolah menyalahkan dirinya atas pernyakit yang diderita anaknya. Membutuhkan waktu selama dua minggu 
bagi subjek SR untuk meyakinkan diri bahwa bagaimana pun kondisi anaknya tetap saja merupakan titipan dari Allah Swt dan ia pasti bisa menjaganya. Adapun faktor yang mempengaruhi keikhlasan orang tua yang memiliki anak autisme dalam penelitian ini ialah dipengaruhi oleh pengetahuan agama, sikap sabar, sikap syukur, pemahamaan agama, dan sikap tawakkal.

Saran

Sebagai orang tua yang memiliki anak autisme diharapkan agar tidak terlalu larut dalam keadaan dan sesegera mungkin bisa menerima ketentuan Allah Swt sehingga anak akan lebih cepat mendapatkan penanganan. Pihak keluarga dan lingkungan sekitar juga diharapkan agar dapat memberikan motivasi dan respon positif terhadap orang tua dan anak, karena dengan menerima anak maka orang tua juga akan merasa diterima. Untuk lembaga Pusat Layanan Disabilitas dan Pendidikan Inklusi Provinsi Kalimantan Selatan diharapkan agar dapat menambah infrastruktur baru lebih khusus penambahan ruang terapi. Sebab dengan keterbatasan ruang terapi yang ada mengharuskan adanya dua proses terapi dalam satu ruangan yang menyebabkan kurang kondusif dan dapat mengganggu perhatian anak. Bagi peneliti selanjutnya diharapkan dapat menelaah lebih dalam sejauh mana faktor pemahaman agama, sabar, syukur, keyakinan dan tawakkal dapat mempengaruhi keikhlasan orang tua yang memiliki anak autisme.

\section{Referensi}

Astari, N. R. (2017). Resiliensi Orang Tua yang Memiliki Anak Penyandang Autis di SLB Autism Center Mitra Ananda Colomadu Karanganyar. Skripsi.

Effendi, H. (2020). Belajar Disiplin dari Anak Autisme. https://geotimes.co.id/opini/belajardisiplin-dari-anak-autis/.

Hadjam, L. C. M. N. R. (2011). Validitas Konstruk Ikhlas: Analisis Faktor Eksploratori terhadap Instrumen Skala Ikhlas. Jurnal Psikologi, Vol. 38 No. 2, 199-214.

Kosim, M. (2013). Pendidikan Dari Orang Tua dalam Menyambut Kelahiran Anak. AtTarbiyah, Vol. 4, No. 2, 261-279.

Marettih, A. K. E., \& Wahdani, S. R. (2017). Melatih Kesabaran dan Wujud Rasa Syukur Sebagai Makna Coping Bagi Orang Tua yang Memiliki Anak autis. Marwah: Jurnal Perempuan, Agama dan Jender, Vol. 16, No. 1, 13-31. 
Mujib, A. (2017). Teori Kepribadian Perspektif Psikologi Islam, Edisi Kedua. PT RajaGrafindo Persada.

Mustafa, M. A. (2012). Dahsyatnya Ikhlas. MedPress Digital.

Nakhrawie (last). (2020). Keutamaan Rahasia dan Tawakkal. Pustaka Media.

Ninda Rian Astari. (2017). Resiliensi Orang Tua yang Memiliki Anak Penyandang Autis di SLB Autism Center Mitra Ananda Colomadu Karanganyar. Jurusan Bimbingan dan Konseling Islam Fakultas Ushuluddin dan Dakwah institut agama Islam Negeri Surakarta.

Noor, M., Indriati, G., \& Elita, V. (2014). Pengalaman Ibu dalam Merawat Anak Autis Usia Sekolah. JOM PSIK, Vol. 1, No. 2, 1-12.

Nur Khadijah. (2018). Ikhlas Dalam Beramal Menurut Mufassir. Fakultas Ushhuluddin dan Filsafat Universitas Islam Negeri Sunan Ampel.

Pancawati, R. (2013). Penerimaan Diri dan Dukungan Orangtua terhadap Anak Autis. Psikoborneo, Vol. 1, No. 1, 23-27.

Pittari Mashita Purnomo,. (2015). Penerimaan Orang Tua Terhadap Anak Penderita Autis di Surakarta. Fakultas Psikologi Universitas Muhammadiyah Surakarta.

Sentana, A. (2011). Revitalisasi Insan Ikhlas:Teknik Harmonisasi Jiwa, Hati, Pikiran, dan Perbuatan, Menuju Kebahagian Sejati. Erlangga.

\begin{tabular}{|c|c|c|c|c|}
\hline Submit & Review & Revisi & Diterima & Publis \\
\hline $15-06-2021$ & $\begin{array}{l}03-07-2021 \text { sd } \quad 08-07- \\
2021\end{array}$ & $10-07-2021$ & $22-07-2021$ & $04-02-2022$ \\
\hline
\end{tabular}

\footnotetext{
Abdussamad, Mulyani, dan Mahdia Fadhila

Program Studi Psikologi Islam

Fakultas Ushuluddin dan Humaniora

Universitas Islam Negeri Antasari Banjarmasin
}

Email: 4bdussamad@gmail.com 